\title{
WAYS OF INFORMATION TECHNOLOGY TERMINOLOGY FORMATION
}

Nowadays, science and technology terminology is characterized by constant emergence of new words due to the rapid development of these fields. Terms are often the most important words of the message, as they present scientific and technical concepts revealing the semantic meaning of the message. Although, increasing use of new terms often results in misunderstanding among specialists from different countries. That is why, there is a need to standardize the subject field terminology in order to build a unified information space and ensure effective communication of scientific communities and specialists in the specific subject field.

Today, there is a growing emphasis on translation skills development of IT specialists who work in international environments and should be able to discuss different issues referring to their subject field. The lack of knowledge of structural and semantic peculiarities of the terms causes difficulties in translating and interpreting the subject field matter.

The main terminological problems are revealed in the works of many Ukrainian and foreign scholars, in particular, R. Kyiak, T. Kandelaki, I. Arnold, D. Lotte, O. Superanska, A. Reformatskyi, Halliday at al. Some issues of the subject field terminology are highlighted by V. Karaban, A. Kovalenko, L. Chernovatyi, A. Nikolaieva, K. Valeontiis, L. Sasu at al.

The purpose of the study is to reveal the ways of IT terminology formation and analyze current word-building and semantic processes in IT-field terminology in English and Ukrainian languages. This is caused by the need for a qualitative translation of this subject field terminology.

Term is generally defined as a word or phrase, designating the concept of a specific subject field [5, p. 57]. According to expert estimates the number of terms in specialized texts accounts for $30-80 \%$ of the vocabulary and the amount of scientific knowledge doubles on average every five - fifteen years [6]. Thus, terminology serves as a tool for transferring and acquiring scientific knowledge.

When creating, defining and systemizing new terms, certain rules should be followed. It is necessary to ascertain whether any term designating a specific concept exists in a specific subject field or, in case there are several synonyms for a concept, one should be selected, which most meets the requirements for the definition [7]. Furthermore, terms should reflect the characteristics of the concepts they refer to as much as possible as they are the linguistic representations of the concepts. Relationships between concepts and terms are based on linguistic appropriateness, linguistic economy, and derivability [8, p. 4].

In order to eliminate misunderstanding among scientists belonging to different cultures, terms should be clear, concise, unambiguous and consistent [4, p. 32].

Scientific and technical terms can be classified by their structure, meaning, usage and ways of formation. According to T. Kandelaki, terms can be divided into four main categories due to the fields of knowledge and activities, in particular, general science and common technical terms, subject field and field specific terms [2].

All these groups can be distinguished among the terms of IT-field: subject field terms, which are used to denote concepts referring only to IT-field (e.g., central processing unit, random access memory, hardware, software, etc.); field specific terms that designate concepts and processes related to the specific subfield (e.g., graphics and design (raster graphics, bitmaps, primitives, texturing, fractals, GPEG); technical terms, which are common to all technical fields (e.g., amplifier, voltage, voltmeter, semiconductor), and general science terms that refer to all fields of Science and Technology and denote logical and philosophical categories (e.g., system, formulae, element, program, function, etc.). Moreover, IT-field terminology includes terms related to other fields of Science, i.e., Mathematics, Physics, Philology, which acquire specific meanings in the speech of IT specialists (attribute, integral, polygon, heading, lexicon, language, translation).

The formation of new terms is based on the existing language vocabulary and is caused by the need to invent new concepts for further development of scientific knowledge [6]. Term formation is influenced by many factors including the level of the subject field development, the nature of the persons involved in this process, the structure of the language, and the stimulus affecting term formation [8]. It is determined by synonymous, hyponymic and antonymic relationships as well as by the process of conversion [5, p. 57]. Among the main ways of term formation, scientists determine the following ones:

- semantic narrowing of the meanings of the commonly used words, which have the varied meanings in different contexts (terminologazation);

- terminological derivation, that is, the use of word-formation means;

- borrowings from other languages [5, p. 58].

Since IT-field is rapidly developing nowadays, new terms are coming into use while others are becoming outdated. A large amount of terms are created through terminologisation. Some terms that have recently been known only to IT 
specialists are becoming a category of commonly used words due to the wide-spread use of Information Technologies. This process can be regarded as determinologisation or the reverse process of terminologisation [7].

Moreover, some of the professional jargon words may also be included into the subject field dictionaries and considered as professional terms because they have lost their eccentric meanings and can be used to convey the precise meanings of specific concepts or procedures referring to the subject field.

The emergence of new devices causes new technological processes. This is the reason for the use of a large number of neologisms by IT specialists in their subject field speech, which designate scientific and theoretical concepts and require for further scientific definitions at a certain stage of the subject field development. Consequently, lexical neologism is included into the subject field dictionary as a result of the discovery of a new concept.

Three groups of neologisms can be distinguished as following ones:

1) proper neologisms (new lexical units are introduced to denote new objects or processes);

2) lexical neologisms (new lexical units appear to denote already known objects or processes);

3) semantic neologisms (existing lexical unit can change its meaning).

English terminology referring to the field of Information Technology is basically formed by means of morphological (affixation, compounding, conversion, blending, back-formation, acronyms) and lexical-semantic ways of word-formation.

Affixation is the most common way of forming neologisms. New words are created by adding prefixes or suffixes to their roots. Among the most popular prefixes, which are used to form new terms in English for Information Technologies are the following ones: mini- (e.g., minicomputer, miniport, minitower); macro- (e.g., macrocell, macroprocessor, macroassembler); inter-(e.g., interface, internet, interlace); super-(e.g., supercomputer, superfloppy, supersampling); multi- (e.g., multiaccess, multiclick, multimedia); hyper-(e.g., hypertext, hypermedia); non- (e.g., nonvolatile, nonpaged, nonbuffered). Such prefixes as dis-, mis-, over-, out-, re-, un- are also widely used (e.g., disconnect, misbug, overlay, output, reboot, update). The most productive suffixes are as follows: -ing; -tion; -er; -or (e.g., processing, spacing; computation, application, emulation, encryption; register, printer, processor).

In Ukrainian language, terms of this field are formed mostly by means of the suffixes -аці(я), -уван (юван), -анн, -енн (автоматизація, автокореляція, анулювання, фільтрування, перемикання, завантаження) and prefixes of Latin and Greek origin such as: гіпер- (гіпертекст), міні- (міні-комп ютер), макро- (макровиклик), мульти(мультимедіа), супер- (суперскалярність).

In both languages, compounding is widely used as a way of word-formation. In this case, two or more already existing words are combined in a new word. In terms of its semantic motivation, such a word is related to the phrases on the basis of which it has been created. Its constituents have mainly denotative meanings, and due to their combination the meaning of the whole phrase resides in one word. Compounds can be distinguished as endocentric (which have a head, e.g., homepage, flash card, database) and exocentric (without a head, e.g., download, upgrade, playback). In Ukrainian language a large amount of words formed by means of compounding have an unchangeable first component, for ехатple, веб-дизайнер, веб-сторінка, веб-вузол, інтернет-безпека, інтернет-провайдер, інтернет-пристрій.

A certain amount of IT terms existing in English language are introduced into other languages by means of borrowing. This is caused by a high level of IT technology development in English speaking countries. Some of the borrowings have successfully come into use in the target language while others have been replaced at a later stage by more compliant words with the linguistic rules of the target language. English terms can be introduced into Ukrainian language according to the following rules: graphic representation of the terms without any changes, in particular, terms designating the names of companies, search engines, types of software (e.g., Apple, Google, Yahoo, Coral Draw); transcribing (e.g., сасhе - кеш, pixel - піксель, file - файл); transliteration (e.g., processor - nроиесор, тодет модем, топіtor-монітор); calque (e.g. front projection-фронтальна проекиія, absolute assembler-aбсолютний асемблер).

Conversion or zero derivation is a way of word-formation when a word is created without any change in its form. The most productive forms of conversion referring to IT terminology are verb to noun conversion (e.g., to plug in plug-in) and noun to verb conversion (e.g., access - to access, host - to host).

One more way of IT terminology formation is reversion or back-formation, that is, derivation of terms by removing affixes (e.g., doubleclick from doubleclicking, to multitask from multitasking).

Blending is a way of word-formation when a new form of a word is created by combining only parts of words. Such a word has the features of both words that influence on each other. For example, netiquette is networked etiquette, which was formed from network and etiquette; Fortran is a programming language, a word was created from formula and translation.

There are many IT terms, which consist of two or more words. Therefore, acronyms are widely used to simplify the process of professional communication or reading, for example, RAM, ROM, LCD, PDF, etc. Typical for IT terminology is also the use of multi-word terms consisting of symbols and acronyms or abbreviations (e.g., 4-GL - Fourth Generation Language, IA 64 - Intel Architecture-64bit, mp3 - MPEG-1 Audio Layer-3, 100BaseVG). Abbreviations are widely used in Ukrainian language as terms are often cumbersome and inconvenient in use, (е. g., ЛОМ-локальна обчислювальна мережа, ОЗП - операційний запам'ятовуючий пристрій, ПЗ - програмне забезпечення, ПЛМ програмована логічна матриия).

A large number of neologisms referring to IT-field appear as a result of new semantic meanings of the already existing language units. Lexical-semantic method of IT terminology word-formation is represented by metaphors and 
metonymies. Thus, such commonly used words as bug, Trojan, wallpaper, wizard, to burn, to hang, to buzz, etc. have acquired new meanings in professional speech of IT specialists.

In case of metonymy the sense of an object is revealed by means of the use of the word designating the other object, which is closely interrelated with the first one. Such relationship can be seen between the subject and the material, which the subject is made from (plasma/plasma screen; silicon/silicon chip); between the process and its result (to interpret/interpretation); between the action and the tool of the action (browse/browser). There are also wide-spread examples of the use of IT terminology when a term denoting a part of something refers to the whole of something (processor/microprocessor) or vice versa (computer/minicomputer).

Summarizing the above-mentioned, we can conclude that both English and Ukrainian IT terminology systems are continuously and dynamically developing and new neologisms appear to denote new objects and processes of IT-field. These terms are coined according to the existing rules of formation in each language. The most productive ways of term formation in English language can be distinguished as follows: affixation, compounding, conversion, acronyms. In Ukrainian language terms are formed mostly by means of suffixes, compounding, borrowings and acronyms. Lexical-semantic way of word-formation is used in both languages. Therefore, the process of term formation represents changes in society, which promote vocabulary replenishment under current conditions of scientific and technical development and is a promising direction for further research.

\section{Bibliography:}

1. Англо-український тлумачний словник з обчислювальної техніки, Інтернету і програмування. 2-ге вид. / Е.М. Пройдаков, Л.А. Теплицький. Київ : СофтПрес, 2006. 824 с.

2. Канделаки Т.Л. Значение терминов и системы значений научно-технических терминологий. Проблемы языка науки и техники: логические, лингвистические и историко-научные аспекты терминологии. Москва : Наука, 1970. C. 19-92.

3. Карабан В.І. Переклад англійської наукової і технічної літератури. Граматичні труднощі, лексичні, термінологічні та жанрово-стилістичні проблеми. Вінниця : Нова книга, 2004. 576 с.

4. Лотте Д.С. Основы построения научно-технической терминологии. Москва : Изд-во АН СССР, 1961. 158 с.

5. Мацько Л.І., Кравець Л.В. Культура української фахової мови : навчальний посібник. Київ : Академія, 2007. $360 \mathrm{c}$.

6. Bozdechova Ivana. Word-formation and technical languages. URL: https://sites.ff.cuni.cz/ucjtk/wp-content/uploads/ sites/57/2015/11/Word-formation-and-technical-languages.pdf (access date: 16.01.2019).

7. Sasu Laura. Terminology dynamics-conceptual patterns of term formation. Bulletin of the Transilvania University of Brasov. Vol. 2 (51), 2009. Series IV. URL: http://webbut.unitbv.ro/bu2009/BULETIN2009/Series\%20IV/BULETIN\%20 IV\%20PDF/28_Sasu.pdf (access date: 16.01.2019).

8. Valeontis Kostas, Mantzari Elena. The linguistic dimension of terminology: principles and methods of term formation. Proceedings of the 1-st Athens International Conference on Translation and Interpretation Translation: Between Art and Social Science, 13-14 October 2006. URL: http://www.eleto.gr/download/BooksAndArticles/HAU-Conference2006ValeontisMantzari_EN.pdf (access date: 16.01.2019).

\section{References:}

1. Anglo-Ukrayinskiy tlumachnyi slovnyk z obchysliuvalnoyi tekhniky, Internetu I prohramuvannya. 2-he vydannia (2006) [English-Ukrainian explanatory dictionary for Computer tecnology, Internet and programming. 2d ed.] / E.M. Proydakov, L.A. Teplitsky. Kyiv : SoftPress, 824 [in Ukrainian].

2. Kandelaki T.L. (1970). Znacheniye terminov $i$ sistemy znacheniy nauchno-tekhnicheskikh terminologiy. Problema yas$y$ ka nauki i tekhniki: logicheskiye, lingvisticheskiye $i$ istoriko-nauchnyye aspekty terminologii [Meaning of terms and value systems of scientific and technical terminology. Problems of the language of science and technology: logical, linguistic, historical and scientific aspects of terminology]. Moscow : Science, 19 - 92 [in Russian].

3. Karaban V.I. (2004). Pereklad anhliyskoyi naukovoyi i tekhnichnoyi literatury. Hramatychni trudnoschi, leksychni, terminolohichni ta zhanrovo-stylistychni problemy [Translation of English scientific and technical literature. Grammatical difficulties, lexical, terminological and genre-stylistic problems].Vinnitsa: Nova Kniga, 576 [in Ukrainian].

4. Lotte D.S. (1961). Osnovy postroyeniya nauchno-tekhnicheskoy terminologii [Basics of building scientific and technical terminology]. Moscow : Publishing house AN USSR, 158 [in Russian].

5. Matsko L.I., Kravets L.V. (2007). Kultura ukrayinskoyi fakhovoyi movy: navchalnyi posibnyk [The culture of Ukrainian professional language: manual]. Kyiv : Academy, 360 [in Ukrainian].

6. Bozdechova I. Word-formation and technical languages. Retrieved from: https://sites.ff.cuni.cz/ucjtk/wp-content/ uploads/sites/57/2015/11/Word-formation-and-technical-languages.pdf.

7. Sasu L. (2009). Terminology dynamics-conceptual patterns of term formation. Bulletin of the Transilvania University of Brasov, 2 (51), IV. Retrieved from: http://webbut.unitbv.ro/bu2009/BULETIN2009/Series\%20IV/BULETIN\%20 IV\%20PDF/28_Sasu.pdf.

8. Valeontis K, Mantzari E. (2006). The linguistic dimension of terminology: principles and methods of term formation. Proceedings of the 1-st Athens International Conference on Translation and Interpretation Translation: Between Art and Social Science, 13-14 October. Retrieved from: http://www.eleto.gr/download/BooksAndArticles/HAUConference2006-ValeontisMantzari_EN.pdf. 


\section{Summary \\ I. SHYLINSKA. WAYS OF INFORMATION TECHNOLOGY TERMINOLOGY FORMATION}

The present study deals with the problem of IT terminology formation. Current word-building and semantic processes in IT-field terminology, which determine the functioning of terms, are analyzed. Rules, which should be followed while creating, defining and systemizing new terms, are highlighted. Peculiarities of scientific and technical terms are revealed and their types are shown. The factors influencing new terms emergence and formation are revealed. The groups of neologisms referring to IT-field are determined. The most productive ways of term formation in English and Ukrainian languages are shown.

Key words: terminology, ways of term formation, IT-field.

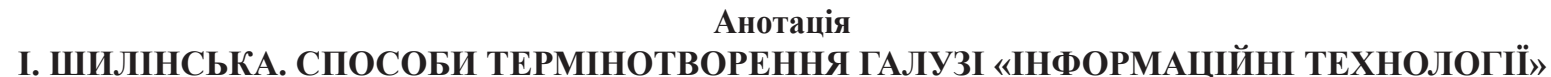

У статті проаналізовано сучасні тенденції термінотворення у галузі «Інформаційні технології», які спричинені стрімким розвитком науки і техніки. Оскільки терміни є найбільш значущими словами з погляду смислового навантаження тексту і кількісно можуть сягати $80 \%$ від загальної кількості лексичних одиниць повідомлення, успішність комунікації між фахівцями і науковцями, які представляють різні культури, а отже і вирішення професійних проблем, залежить від того, чи зможуть фахівці та представники наукових спільнот досягнути порозуміння в процесі комунікації. Це можливо лише за умови адекватного перекладу термінів, які являють поняття галузі і сприяють утворенню єдиного інформаційного простору.

Оскільки галузь «Інформаційні технології» найбільш стрімко розвивається нині, це спричиняє і розвиток терміносистеми цієї галузі, яка характеризується появою нових термінів та виходом із ужитку інших термінів. Отже, актуальність дослідження зумовлена необхідністю визначення основних способів творення терміносистеми IT-галузі задля адекватного перекладу термінологічних одиниць представниками різних культур.

У статті представлено класифікацію ІТ-термінів та визначено фактори, що впливають на їх формування. У результаті аналізу лексики галузі «Інформаційні технології» виявлено, що англійська й українська терміносистеми постійно і динамічно розвиваються. Нові терміни виникають як результат пізнавальної діяльності представників галузі. 3-поміж основних способів творення англомовної термінології ІТ-галузі виокремлено такі: афіксація, словоскладання, конверсія та скорочення, які представлені абревіатурами та акронімами. В українській мові найбільш продуктивними способами творення IT-термінів є суфіксація, словоскладання, запозичення та скорочення. Зазначено, що лексико-семантичний спосіб, результатом якого є переосмислення значень уже наявних у мові слів (метафора, метонімія), притаманний як англійській, так і українській мовам.

Ключові слова: термінологія, способи творення термінів, ІТ-галузь. 